\title{
SECONDARY SCHOOLS IN THE DISCUSSIONS OF THE FIRST HALF OF THE $20^{\mathrm{TH}}$ CENTURY
}

\author{
Jaroslav Vaculík
}

\begin{abstract}
The paper deals with the views of proponents and opponents of the introduction of the system of uniform secondary schools in the first half of the $20^{\text {th }}$ century.
\end{abstract}

\section{Key words}

School system, uniform school, first half of the $20^{\text {th }}$ century.

\section{Resumé}

Příspěvek se zabývá názory stoupenců a oponentů jednotné základní školy 2. stupně v první polovině 20. století.

\section{Klíčová slova}

Školství, jednotná škola, první polovina 20. století.

The character of secondary schools had been subjected to criticism since the turn of the $19^{\text {th }}$ and $20^{\text {th }}$ century. Already more than a hundred years ago T. G. Masaryk called for the reform of secondary schools; he saw - as their specific defects - their heterogeneity, excessive intellectualism, neglect of the development of feelings and will, excessive workload of pupils, cult of detailed facts at the expense of thinking, lack of a unifying spirit, neglect of natural and social sciences, and insufficient moral education. ${ }^{1}$

The reform of the secondary school system was also discussed by the professional community. Already in 1919, the Ministry of Education (MŠANO) conducted a poll the results of which were published in 1922. In the same year the publication "K reformě střední školy" (Secondary School Reform) by secondary school teachers Jan Čeněk and Přemysl Hájek was published by

${ }^{1}$ MASARYK, T. G. Jak pracovat. Praha: Čin, 1928, 74 pp. 
the State Publishing House. J. Čeněk warned that "reducing the educational level of secondary schools out of an ideal unhealthy effort for them to serve the broadest possible masses means reducing the cultural level of the nation at all. It must not be forgotten that it is not possible for all sections of the nation to receive higher education." ${ }^{2} \mathrm{He}$ rejected the argument that the existing secondary schools only served children of wealthy parents, and argued that to the contrary, the Czech secondary schools were filled with children of poor parents, and a number of leading intellectuals grew up in a poorer environment. In 1930, E. Čapek in his book "Sto hlasů o střední škole" (One Hundred Votes About High School) published the results of the polls in which the majority opposed to a uniform school. For example Prof. Dr. F. Chudoba expressed his concern about the monotony of the school system because monotony deadens both the individuals and the nation. ${ }^{3}$

In the thirties Social Democrats concentrated around "Dělnická akademie" (Workers' Academy) in their action plan "Co chtějí socialisté" (What The Socialists Want) demanded a uniform school system differentiated according to student abilities and needs and incorporating all schools into a uniform system to maximize the possibility of transition. Compulsory school attendance should have been extended to 16 years of age. According to the Socialists, education was a right for all, not a privilege of some. ${ }^{4}$

After the Second World War the President Dr. E. Beneš got involved in very intense debates on secondary schools in his speeches to teachers and school staff in 1947. The President urged that the implementation of uniform schools should be free from a dogmatic bias and leave the possibility of changes according to subsequent experience and diversity of implementing conditions. $\mathrm{He}$ therefore recommended early differentiation with respect to a variety of pupils' giftedness and the direction of their future work.

In his speech to a deputation of secondary school teachers in the Union of Employees of Schools and Further Education Institutions on $19^{\text {th }}$ March 1947 the President stated that he was not against reforms, but expressed his hopes that the theory of the reforms would be very well-thought-out, the reforms would be practically well-proven and prepared by cooperation of competent experts. ${ }^{5} \mathrm{He}$ expressed his appreciation of the importance of the secondary

${ }^{2}$ ČENĚK, Jan - HÁJEK, Přemysl. K reformě střední školy. Praha: Státní nakladatelství, 1922, p. 7.

${ }^{3}$ ČAPEK, Emanuel. Sto hlasů o střední škole. Praha: Nové Čechy, 1930, 181 pp.

${ }^{4}$ BĚHOUNEK, Václav. Co chtějí socialisté. Praha: Dělnická akademie, 1934, pp. 44-47.

${ }^{5}$ BENEŠ, Edvard: O školské reformě. Praha: Pokrok, 1947, p. 17. 
school system, which in its current form shaped the Czech intelligentsia both for life and for study at universities. He pointed out that its basis was formed a century ago and that it therefore needed to reform: "However, it is necessary to reform just such parts of it which really need reforms... it is not about levelling out and eventually standardizing the average, if not the below the average." 6 He warned against the imitation of the West or East and against coercing the solutions "which we would change the next day or two." ${ }^{7} \mathrm{He}$ called for early differentiation of pupils according to their aptitude and abilities, as in his opinion the natural inequality and dissimilarity of people was the reality. He pointed out that the public opinion got out of the balance due to the war and May revolution, as reflected also in the assessment of issues related to the reform of the school system.

On $5^{\text {th }}$ April 1947 Dr. Beneš said to the representatives of professors of the Prague Faculty of Philosophy and Faculty of Science that the reform of secondary schools should be based around the fact that after a two-year common base, differentiation should be made already from the third grade according to the pupils' talents. At the senior secondary school the differentiation could then escalate to the direct introduction in the university studies. According to Beneš, the university was supposed to exactly specify what the secondary school should give to its graduates; and in turn the secondary school was supposed do anything so that its graduates do not have to overcome the gap between the secondary school and university. He pointed out that two foreign languages (one western language and Russian) should be taught already in the junior secondary school.

In an interview with a group of reform school workers led by the Rector of Charles University Prof. Dr. B. Bydžovský on $23^{\text {rd }}$ April 1947 the President said that he considered the principle of uniform schools in our country essentially correct and viable. He expressed the wish that all reforms should be made after the agreement of the widest possible circle of interested people.

The President said to the deputation of the Union of Employees of Schools and Further Education Institutions, which visited him on $25^{\text {th }}$ April 1947, that the differentiation should be applied in time. He spoke against a rushed and hasty discussion of such important issues. This indicates that the President was not against uniform schools, but demanded their differentiation.

Unlike the President, who had to use a diplomatic language, other discussants expressed their views regarding the uniform school system much more

\footnotetext{
${ }^{6}$ Ibidem, p. 16.

${ }^{7}$ Ibidem, p. 17.
} 
openly. Already in July 1945 the psychologist Dr. Robert Konečný called for dropping the scheme of the uniform school system: "The secondary school should be the school of a special type, teaching Latin from the first grade; a strictly selective type; the type of elite of gifted people. And it should be open to all without distinction if they meet the requirement of exceptional education... Otherwise we will have what we have already had: studied semi-intelligentsia, graduating on a massive scale, neither fish nor fowl."

According to the draft basic law on education, by introducing a uniform undifferentiated school of the $2^{\text {nd }}$ level the current junior secondary school was supposed to disappear. Mainly the teachers of general and "town" schools expressed their views in favour of the uniform school. As opposed to this, the cultural public and almost without exception all professorial staffs and headmasters of secondary schools expressed their views which were against the undifferentiated uniform school. Also parents' associations in secondary schools opposed the uniform school.

The main promoter of the uniform school was Dr. František Kahuda, then the employee of the Research Institute, later in 1956-1963 the Communist Minister of Education; he claimed that the uniform school would contribute to maintaining the unity of the nation and that earlier only the rich were given an opportunity to study. The Communist Minister of Education in the years 1945-1946, Prof. Dr. Zdeněk Nejedlý, stated that the goal of the uniform school was "to remove this impossible distribution of youth when a decision is made even for a ten-year-old boy whether he will or will not be a master. This is the main reason for a uniform school and a uniform second level."

After the war the opponents of the uniform school warned that after the destruction of the junior secondary schools the Communist Party of Czechoslovakia would remove the existing senior secondary schools as well and introduce the whole secondary school as a uniform school (i.e. both $2^{\text {nd }}$ and $\left.3^{\text {rd }} l e v e l\right)$. And indeed, in 1973 the July plenum of the CPC Central Committee approved the project of the new educational system, which was supposed to achieve a maximum approximation of the secondary schools of general education, secondary vocational schools and secondary apprenticeship training schools.

According to some newspaper articles published after the war our entire history until $9^{\text {th }}$ May 1945 was worth nothing, everything in it was wrong, outdated, reactionary, anti-social and anti-democratic; true happiness occurred only

\footnotetext{
${ }^{8}$ Svobodné noviny. Praha: Sdružení kulturních organizací, 10. 7. 1945.

${ }^{9}$ MERTLÍK, Rudolf. Nebezpečí jednotné školy. Praha: V. Petr, 1947, p. 13.
} 
after the May Revolution. The educational system of the First Czechoslovak Republic was also reportedly worth nothing, not to mention old Austria. And it was therefore necessary to reform it at any cost. Who dared to say that it was something good even in past times, was declared a reactionary. Demagogic lies were repeated stating that previously only those socially strong had received training and that "a less gifted pupil of wealthier parents... finally got a better assessment than a pupil who was socially weaker, but talented". ${ }^{10}$

The spiritual father of uniform, but differentiated schools was Dr. Václav Přihoda. But the Communists no longer spoke about differentiation, but manifested that the uniform undifferentiated school would be introduced whether people liked it or not. The statement that a uniform school of the $2^{\text {nd }}$ level (i.e. after the merger of the existing "town" schools with the first four classes of gymnasiums) would provide students the broadest and deepest of education was, in the first place, doubtful because it was not supposed to teach classical languages. Prof. Dr. H. Vysoký had already spoken against restrictions on Latin and Greek since our culture in its entirety rested, as on a granite pillar, on the ancient culture and there would be no genuine education without this culture.

Many teachers, especially secondary school professors, warned that the undifferentiated school of the $2^{\text {nd }}$ level would be an educational and social injustice committed on pupils since on one hand it would be too demanding for some, and on the other hand the gifted students would not receive as much as they would be entitled to in accordance with their talents and abilities. Uniform schools would not create conditions for laying solid foundations of language education in an age when memory is receptive to learning foreign languages either.

The biggest mistake in the preparation of a school reform was that this issue became a political issue. Another basic mistake was that the major part of the reform was prepared by teachers who never got to know secondary schools of the gymnasium type, i.e. the teachers of the "town" schools who, after finishing the "town" school, studied at the Teachers Institute. In practice the draft presented by the Reform Commission virtually meant the destruction of the current level of secondary schools.

An alternative draft was submitted in May 1946 by Prof. Dr. V. Hlavatý, who recommended the introduction of two joint years of the uniform school of the $2^{\text {nd }}$ level, which would then, in the $3^{\text {rd }}$ and $4^{\text {th }}$ year, part into two branches. The first branch would give education for practical life to those who do not intend to study, the second branch would prepare for further study. The distribution

${ }^{10}$ Svobodné noviny. Praha: Sdružení kulturních organizací, 17. 9. 1946. 
of pupils in these two branches would be subject to their study results in previous years. ${ }^{11}$

Another solution that would eliminate or alleviate the defects of uniform undifferentiated schools was prepared by Jan Čeněk, the secondary school professor. According to him, the school of the $2^{\text {nd }}$ level should have three years of uniform undifferentiated schooling, which would provide closed general education. The fourth year would be targeted and differentiated according to pupils' future professions. ${ }^{12}$

Some tried to remove the disadvantages of uniform undifferentiated schools of the $2^{\text {nd }}$ level by internal differentiation, i.e. by splitting the class into groups according to pupils' talents and hobbies, where the same teacher would teach in joint lessons. The national-socialist Minister of Education in the years 1946-1948, Prof. Dr. Jaroslav Stránský, suggested that the common basic education of pupils aged 11-15 should be supplemented by a set of optional subjects, by which gifted pupils would receive at least a partial necessary preparation for the $3^{\text {rd }}$ level. Such optional subjects could be, for example, a foreign language, Latin, laboratory exercises, etc.

In his book "Nebezpečí jednotné školy" (The Danger of Uniform School) Rudolf Mertlík warned, inter alia, against the problem of foreign languages. $\mathrm{He}$ stated that the post-revolutionary enthusiasm for Russian had faded with almost all pupils: "And not only faded, many even developed resistance to it, for we cannot ignore that Russian substitutes Protectorate German ... in addition, it is being taught with an ideological tone and it has received a kind of an official stamp." ${ }^{13} \mathrm{He}$ reminded that German had been forgotten and pointed out that a graduate of a traditional gymnasium at the time of old Austria was really knowledgeable and well educated, because no subjects of a training or practicing nature were introduced in this type of schools. The traditional gymnasium did not look at what students would need in practice, but provided good education.

Already in 1945, Prof. Dr. F. Novotný said in "Národní obroda" (The National Revival) that pointing out that the organization of our secondary school system was a hundred years old proved nothing in itself, since for example the democratic system had already existed from the $5^{\text {th }}$ century BC. He did not consider as very good the slogan 'socialization of education' either, since education could not be socialized as mines or banks; education had to be conquered by

\footnotetext{
${ }^{11}$ Ibidem, 30. 5. 1946.

${ }^{12}$ Naše doba. Praha: J. Laichter, 1946, p. 241.

${ }^{13}$ MERTLÍK, Rudolf. Nebezpečí jednotné školy. Praha: V. Petr, 1947, p. 49.
} 
proper work of each and every person individually. He said that a radical reform of the school system would be an attempt for which we would pay heavily, and after the implementation of which we would gradually over time do away with the reform and approach the status quo. ${ }^{14}$

The idea of undifferentiated uniform schools of the $2^{\text {nd }}$ level, as sought by the Communists, was rejected by educational officials of the Czechoslovak NationalSocialist Party, the Czechoslovak People's Party, the Slovak Democratic Party and the Roman Catholic Church, who - in the summer of 1946 - called for a differentiated second level. The discussions over the Basic Education Act, accompanied by demagogy, ended only in April 1948 when, after the February coup, the Communists had a free path to the introduction of undifferentiated schools of the $2^{\text {nd }}$ level.

\section{Literature}

1. BĚHOUNEK, Václav. Co chtějí socialisté. Praha: Dělnická akademie, 1934. $52 \mathrm{pp}$.

2. BENEŠ, Edvard. O školské reformě. Praha: Pokrok, 1947. 40 pp.

3. ČAPEK, Emanuel. Sto hlasů o střední škole. Praha: Nové Čechy, 1930. 181 pp.

4. ČENĚK, Jan - HÁJEK, Přemysl. K reformě střední školy. Praha: Státní nakladatelství, 1932. $67 \mathrm{pp}$.

5. MASARYK, Tomáš Garigue. Jak pracovat. Praha: Čin, 1928. 74 pp.

6. MERTLÍK, Rudolf. Nebezpečí jednotné školy. Praha: V. Petr, 1947. 63 pp.

7. Národní obroda. Brno: ČSL, 1945.

8. Naše doba. Praha: J. Laichter, 1946.

9. Svobodné noviny. Praha: Sdružení kulturních organizací, 1945-1946.

\section{Contact address:}

Jaroslav Vaculík, Prof. PhDr., CSc.,

Faculty of Education, Masaryk University, Brno,

Poříči 9, 60300 ,

tel. 549497 470, fax 549491620 ,

e-mail: vaculik@ped.muni.cz

${ }^{14}$ Národní obroda. Brno: ČSL, 14. 7. 1945. 